\title{
URBAN MOVEMENTS IN THE PROCESS OF THE LEGITIMATION OF LIBERAL DEMOCRACY: ANALYSIS OF THE ACTIVITIES OF ALTERNATIVE GROUPS AND CIVIL ORGANISATIONS AT A TIME OF EUROPEAN CRISIS ${ }^{1}$
}

\author{
BARBARA LEWENSTEIN ${ }^{1}$ \\ ${ }^{1}$ University of Warsaw, Institute of Applied Social Sciences, Nowy Świat 69, 00-927 Warsaw, Poland. \\ ORCID: 0000-0001-7609-7775, Email: lewensteinb@gmail.com
}

\begin{abstract}
This paper constitutes an analysis of urban movements, marked in the research as alternative groups and civil organisations, in terms of the new politics characteristic of new social movements. In particular it indicates that these movements, ostensibly urban, actually express demands towards the broader social system, delegitimating it in a twofold manner. Firstly, the acceptance of certain general principles in democratic values and rules is coupled with criticism of how the system functions in practice and of the political elites in Poland, via protest, lobbying, and watchdog activities. A separate type of delegitimation embraces organisations among which we may list cooperatives and squats, as well as organisations managing concrete spaces and withdrawing from participation in public life, shutting themselves away within autonomous spaces and realising a different cultural and democratic model. In both of these groups we are thus dealing with a strongly accentuated anti-systemic and anti-capitalist attitude towards the political reality of the period of transformation in Poland. The research delivered confirmation of the overall research hypothesis ad-

\footnotetext{
${ }^{1}$ The article is based on research conducted within the project Livewhat: 'Living with Hard Times: How Citizens React to Economic Crises and Their Social and Political Consequences.' Research was conducted in a team with M. Theiss, E. Zielińska and J. Petelczyk. This publication is based on an article written jointly with M. Theiss: 'Obywatele w polityce nieinstytucjonalnej. Analiza działan alternatywnych grup i organizacji społecznych w sytuacji kryzysu ekonomicznego' contained in the collective volume: $\mathrm{M}$. Theiss, A. Kurowska, J. Petelczyk B. Lewenstein. 2017. Obywatel na zielonej wyspie. Polityka społeczna o obywatelstwo społeczne w Polsce $w$ dobie europejskiego kryzysu gospodarczego. Warszawa: IFiS PAN.
} 
opted in the Lifewhat project, according to which in response to economic crisis civil society responds with the emergence of alternative forms of resilience, not only alleviating the consequences of the crisis but which also, as time passes and the scale of their activities increases, may give rise to a new quality - including in a political sense. The research constitutes a part of the international Lifewhat project. It was conducted on a sample of eighteen purposefully selected civil groups and organisations operating in large cities in Poland, using the method of in-depth interviews.

KEYWORDS: urban movements, new social movements, politics, delegitimation of the political system

\section{INTRODUCTION}

The blossoming in urban movements tackling important social issues in various forms noticeable in recent years has most often been understood to date as them implementing the Lefebvrian demand for the 'right to the city', in which the addressees of their claims are urban politicians (Lefebvre 2012; Pobłocki, Mergler \& Wudarski 2013; Harvery 2012). However, as certain writers have observed (Kowalewski 2019; Castells 2013), issues such as ignoring the voice of the citizens, the superficiality of democracy, the priority of capital over the interests of the residents, small shops being displaced by chains of discount stores, and cuts in council housing or underinvestment in culture are problems that are systemic in character, while simultaneously bearing a local dimension. The activity of these movements should therefore be understood in a broader sense: in relation to the entire social-political system, and not making do with placing them solely in urban contexts, even if that is where urban activists situate their demands. The question that therefore arises is whether urban movements are, in essence, movements characterised by some kind of urban marker, or can we treat them as an element of the broader landscape of activism embracing contemporary societies, especially following the economic crisis that Europe experienced, and which in literature are termed new social movements, or - as Manuel Castells would have it - networks of Hope and Outrage (Castells 2013). It would seem that a significant portion of urban movements may be treated in precisely such a manner, while the 'right to the city' that they express is, in many cases, essentially an expression of the civil right to question the broader social order, not limited exclusively to urban matters. The foundations of numerous claims regarding purely urban matters, such as for example the protection of green land in a city, or a protest aimed at curtailing large-format trade in specific city districts, essentially comprise assumptions stretching far beyond the urban context (though expressed in the language of one's right to the city), and resolving them also sometimes requires specific political decisions and changes to the political system. Then urban movements thus defined become political movements, even when the activists do not explicitly refer to politics. In a word, it is the interpretation of the researcher that ultimately positions them in the broader field of politics, and not the intentions of the actors, which may contradict this interpretation. Nevertheless, by considering the demands put forward, and analysing the 
measures taken by the entities investigated along with their accompanying values, we can conclude to what extent they express acceptance for the existing broader political status quo, and to what degree they are an expression of opposition. We therefore treat such forms of urban activism as participation that can define the degree of legitimacy of the political system. In this paper we shall focus on those forms of participation in politics undertaken by urban groups and organisations that take place not solely via membership in political bodies or involvement in the formal procedures of creating politics (for example via consulting or lobbying for specific legislation), but through non-institutional activities, including outside of the traditional structures of the third sector. At the same time we anticipate that the actors themselves may not have any intention of 'politicality' in their activities, and that we may not discern anything steering us directly in the direction of politics in the missions they formulate.

In this paper, we argue that the above-mentioned political significance of activities undertaken by social urban movements in Poland embraces, among others, the delegitimation of the existing social-political-economic system, and the search for another, new formula by which it could function. The subject-matter of this paper therefore covers showing the character of this delegitimation, meaning in relation to which areas of life in society, which aspects of the political system or political practices, urban activists are protesting against, and what type of politics they represent. We put forward the hypothesis that the urban movements' representatives covered by our analysis are creating a new kind of politics, a kind characteristic of new social movements in the post-industrial era, movements becoming active especially following the turning point of the economic crisis of 2008-2012 that embraced most countries around the world; in literature, these movements are referred to as new politics (Kołtan 2016). Cities always have been the cradle of democracy and a melting pot of new ideas. This feature of new politics is evident above all in the case of alternative organisations and groups proposing methods for resolving social problems different to mainstream approaches (also prevalent in the non-governmental community), or undertaking innovative social practices - and such constituted the subject of the research. Where this is referred to later on, we focus on organisations and groups whose emergence was directly or indirectly connected to the economic and political situation that developed in Poland during Europe's economic crisis of 2008, and which were capable of expressing a specific stance towards the political system, delegitimating it on certain levels or expressing incomplete legitimacy (Mider 2014: 43).

\section{MOVEMENTS OF OUTRAGE AND HOPE: A NEW DIMENSION OF POLITICS AMONG CIVIL ACTORS}

Many researchers of contemporary urban movements draw attention to a fundamental change of character in how new social movements participate in politics, as well as to the factors evoking civil mobilisation (Touraine 1995; Offe 1995; Castells 2013; Koltan 2016). These researchers acknowledge that the conflict between social classes that characterised the mobilisation processes of the previous era is fading in its significance as an axis organising protest, giving way to all-embracing criticism of the cur- 
rent social order along with demands for the right to be active citizens (Matynia 2016). According to Claus Offe, the new social movements are voicing their opposition to representative democracy and the political institutions functioning within it, and to the manner in which conventional politics - rooted in political parties - is practised, while calling for a more radical form of democracy based on direct participation rather than the intermediation of political parties (Della Porta \& Diani 2009; Offe 1995). They are anti-modernist, and they express scepticism towards the idea of progress; they are in favour of solidarity and seek autonomous spaces for their self-fulfilment. Melucci in turn draws attention to the significance of identity issues as the determinant of new social movements, and the new actors' emphasis on the rights of the individual to define their own identity and resist the state and market encroaching upon their private sphere, as well as the protection of the individual's autonomy. Similarly to Offe, he believes that they are attempting to change the widespread definitions of politics and society. As such, they criticise the current social order in its entirety, while at the same time distancing themselves from politics. Castells had already noticed this ambiguity in regard to politics among urban movements in his excellent book Networks of Outrage and Hope, writing about their political dimension. He said that these movements want to change the state, but do not aspire to take power; they express feelings and aim for discussion, but do not want to form political parties and do not support governments, although they may become an object of political marketing. Apart from that, they are political in the fundamental meaning of that word (Castells 2013: 218).

The manner of protest is also different. The new social movements are not creating coherent political programmes; their place is taken by affects, above all anger and dignity (Castells 2013; Kołtan 2016). As Jacek Kołtan writes, 'Emotions are what make the new actors visible in the public realm (...) by managing the emotional sphere, social actors have made a return to politics' (Kołtan 2016:15).

There are various interpretations of the factors that cause the stimulation of social movements today, and the changes that follow in their manners of mobilisation and articulation. If it is no longer social conflict between the main social classes, in the economic sense, then what processes are energising today's civil agitation?

Many authors are of the opinion that we are living in a turning-point era, brought about by the processes of globalisation, the market's domination, and new technological possibilities - and manifested in, among other things, the economic crisis (Kołtan 2016, 2014; Castells 2013; Della Porta \& Diani 2009; Touraine1995). As Jacek Kołtan writes, 'this wave forced a redefinition of the world in which we live; everything became different, everything called for reinterpretation from scratch, everything demanded rethinking' (Kołtan 2016: 8). Alain Touraine calls this state a post-social situation, while for Beck it is reflexive modernisation, caused by an uprooting of hitherto well-recognised forms of societal life as a consequence of economic crises and growing uncertainty evoked by new areas of risk (Kołtan 2016).

Although literature reveals a search for common characteristics behind new social movements and the global factors responsible for stimulating them, these movements also display a local specificity, and the degree, character, and area of delegitimation 
of the economic system most certainly differs between specific countries, just as the area of uncertainty as well as the plane of outrage varies from one country to another.

\section{DIMENSIONS OF THE SYSTEM'S LEGITIMACY AND URBAN MOVEMENTS}

The relationship between the activity of new social movements and delegitimation of the social-political-economic system may be demonstrated on two levels. Firstly, on the microsocial level, it involves the motivations of social movement activists. In keeping with the hypothesis formulated by Puvergen (1966: 159), conventional forms of political participation, such as voting in elections or referendums, constitute an expression of support for the system, while unconventional forms, which include a broad range of civil activities, are a manifestation of delegitimation of the system and the search for ways to thoroughly transform it. This second form of political participation aims to exert political influence or to publicly express a position in regard to important social issues, and is a response to deficits in ways of articulating opinion and taking action in a conventional way (Mider 2014: 78).

Secondly, as shown above, on the macrosocial level an empirical relationship between such events as the economic crisis and activities expressing delegitimation of the system has been visible over the last decade. Positions speaking of the existence of a crisis in a broader sense, for example in Poland's case understood as the unfair and faulty model of the post-transformation liberal democracy based on capitalist relations of ownership (Pluciński 2014; Jacobsson 2015: 10-13; Herbst 2013), have similar functions to the experience of the economic crisis in western and southern Europe. They also fit the antiliberal turn visible in the activity of urban movements in other countries as well, and in particular in Eastern Europe, which does not have long traditions of a capitalist economy capable of softening perception of the consequences of adopting a sharp liberal direction where economics is concerned (Jacobsson 2015: 10-13; Polańska 2014).

The system's legitimacy, however, is not one-dimensional. Citizens can accept the general values and rules constituting the foundations of a particular political system, and in the case of the organisations investigated here this means the system of democracy, while voicing reservations regarding the way in which it functions, or in other words its social practice, meaning the way in which the said rules and values are realised by government in the life of society (Mider 2014; Beetham 1991; Easton 1965: 297), or - in more detail - withholding full support for institutions of the political system, such as parliament, the courts, or local government. Taking yet another angle, delegitimation of the system may mean focusing on some selected aspect of the political system, for example the unfavourable perception of the activities of politicians, while simultaneously accepting the other dimensions of social and political life (Mider 2014). We are therefore dealing with a certain continuum in how citizens relate to the system: from total legitimation, through partial legitimation, to complete delegitimation, characterised by a negative attitude towards all of the dimensions indicated above, with a consequence of such a situation being the refusal to take part in conventional forms of political participation, and frequently even withdrawal from the 
political system and entering a state of apathy.

The intermediate form that connects the extreme points of this continuum is the situation of acceptance for certain general principles in the values and rules, along with a simultaneous strategy for remediating the system's practice through the intermediation of protest, lobbying, watchdog measures, and so forth. Mider calls such a form of social reaction critical legitimacy (Mider 2014: 46) and, as he writes, it is characteristic of Polish society. It is marked by an attitude of the active citizen, interested in politics and participating in it at the same time, coupled with simultaneous close scrutiny of the activities of politicians on a micro and macro scale. Such an attitude, as he writes, involves a 'highly critical disposition towards those in power, both individual political players and the functioning of such key institutions as parliament or the government' (Mider 2014b:46). He describes such a state as a democratic paradox, in which intense distrust towards the power elites is accompanied by strong belief in the ideals of democracy (Garlicki 2014).

In our opinion, the typology presented by Mider could be broadened to embrace the type defined by Merton with the term innovation, meaning the situation in which - with a defined degree of system delegitimation - alternative forms of practice are sought for expressing the fundamental and accepted principles on which the political system is founded. In this model participation would therefore mean partial withdrawal from mainstream social practices that would legitimate the political system, and the proposal of one's own forms capable of achieving the ideals of democracy to a greater degree. Where urban movements are concerned, an object of criticism could in particular be the practice of governance, specifically institutions whose goal it is to implement these democratic rules and values, as well as the power elites responsible for the said practice (Pluciński 2020; Herbst 2013).

In this text we assume that the activities of urban movements in question have a distinctly political meaning also in those areas which, in many researchers' opinion, are not directly connected to politics. The prevailing currents in source literature discern the politicality of social movements in activities related to the formulating of demands, advocacy, and protest (Kriesi 1996; Baglioni \& Giugni 2014) or the occupying of places in the public realm. However, it is our firm belief that practices related to the provision of services for a community, the exchange of products, and the propagating of fair trade, and so on, also have a political significance. Among other things, it involves the questioning of the foundations of the political and economic system, and the grassroots creation of alternatives to it.

\section{RESEARCH QUESTIONS AND METHODOLOGY}

In regard to the above positions, we pose research questions about the character of delegitimation measures undertaken by selected urban social movements functioning in Poland, and to what extent they are a reaction to the economic crisis of 2008-2012, which set in motion a new dimension of politics, represented by the new social movements. Civil organisations and informal groups, about which one could say in relation to the assumptions thus presented that they are delegitimating the social-political 
and economic system in some way, were selected for the study. We strived in our research to determine, among other things, what the delegitimating actions they undertake actually involve, and which aspects of the social-political and economic system they are aimed at. Where referred to later in detail, we assume that a portion of the activities by the urban movements investigated are situated either within the type of critical legitimacy, or within the type of delegitimation through the creation of innovation proposed for the requirements of this paper.

We obtained data for the analysis from individual in-depth interviews conducted in 2016 with 18 representatives of urban non-governmental organisations and informal social groups meeting the criteria of alternative initiatives and social organisations adopted in the international Livewhat study. ${ }^{2}$ In the countries where the project was carried out, the researchers' attention therefore focused on such organisations and information groups and communities proposing new ways for citizens to cope with everyday difficulties and challenges in economically difficult times. They were defined in the project as organisations promoting alternative ways of coping with the crisis situation. Because of this, state institutions and (in part) local government bodies, plus certain market organisations, were excluded from the research - firstly since they did not constitute an element of civil society, and secondly because the assumption was that such entities tend to function in a standard manner, while our goal was to identify activities extending beyond institutionalised ways of preventing a crisis or reacting to its consequences, and coming up with innovative ideas and methods of work. In the definition of alternative organisations adopted in the project, they were described as entities that had not been established or were not maintained entirely by mainstream political and economic organisations such as government, local government or market bodies. Initiatives were sought within the realms of culture, ecology, economics, social communication, alternative forms of consumption, self-governing spaces, and also politics. Examples given included cooperatives, second-hand goods exchanges, community kitchens, squats, community centres, food banks and time banks, although also of interest were long-term campaigns addressing protest against the consequences of the economic crisis. These alternative initiatives could feature formal organisation or remain informal communities, groups or social movements.

The alternative nature of the organisations covered by the research was identified through analysis of websites, and a coding form was drawn up for this purpose, on which the basic characteristics of an organisation under investigation were marked, including its structure, its main goals and missions, and its methods of activity.

We subjected the interview transcriptions to thematic analysis (Guest 2011), conducted inductively. In the section for the existing social-political and economic order in Poland as well as practical proposals regarding on what grounds an alternative order should be built were explicitly expressed by our interlocutors.

\footnotetext{
${ }^{2}$ The findings contained in this publication were obtained in the research project 'Living with Hard Times: How Citizens React to Economic Crises and Their Social and Political Consequences' (LIVEWHAT). This project was financed by the European Commission in the Seventh Framework Programme (contract no. 613237). Academic work financed with funds for science in the years 2014-2016 allocated for the realisation of an international project.
} 


\section{CRITICISM OF AND ALTERNATIVES TO THE SOCIAL-POLITICAL AND ECONOMIC SYSTEM: ANALYSIS OF REMARKS MADE BY URBAN SOCIAL ACTIVISTS}

\section{RESPONSES TO THE ECONOMIC CRISIS AND DELEGITIMATION OF THE ECONOMIC SYSTEM}

Despite the fact that the official economic indices used most often might prove that Poland has not experienced the economic crisis that embraced numerous countries of Europe after the year 2008, our interviewees frequently drew attention to links between the crisis and their activities. For a start, in general the economic crisis in Europe was, according to many, a circumstance that favoured the maintaining of the 'belt-tightening' austerity trend, including in Poland. Our respondents frequently pointed out that today's politicians in Poland, at a national and local level, are creating or exacerbating the crisis - and in this sense the crisis has a broader political meaning involving the intensifying of self-interested measures, the never-ending introducing of economising measures, and the ignoring of social needs.

A few of our interlocutors also drew attention to the fact that the macroeconomic indicators say nothing about the social reality. Despite official data showing that there was no crisis in Poland, they emphasised that many social groups in Polish society are experiencing poverty and social exclusion. Some organisations understood the economic crisis in broad terms - pointing out that the Polish crisis began together with the start of the transformations, when the introduction of the neoliberal reforms began. One organisation involved in social activity even stated outright that the goal of its operations was to respond to the crisis of the Polish economic and political transformation that began in the year 1989. According to a representative of the said organisation, the consequences of the transformations can still be felt in Poland, because the county's economy and society have to struggle with numerous problems, and the last 10 years have witnessed noticeable changes deepening social injustice.

Another organisation pointed out that the global economic crisis brought about the situation in which Poland is increasingly dependent on investors from countries where social and economic policy is linked to the violation of human rights. These interlocutors stressed, for example, that Chinese investments in Poland are leading to an exacerbation of social-economic problems that this organisation wants to fight.

Therefore, despite the absence of objective economic indices testifying to an economic slump in our country, the respondents perceived the context of their activity as a situation of permanent crisis - which is a general weakness of the capitalist economy. One of the features of the dominant economic model is, in their opinion, the uneven share of riches, imposing poverty on various social groups while also destroying social bonds, mutual relationships, the natural environment (especially urban space), and frequently leading to violations of fundamental human rights, in particular in the global South. As such, one of the main goals of some of the organisations covered by the study is to create an alternative formula for running the economy - based on social bonds and pro-ecological activity, potentially more resistant to the consequences 
of an actual crisis. This is how the founding of a food cooperative was spoken about by its representative:

this is precisely the answer to the sort of crisis that was, that capitalism is not everything, because this and also many people in the cooperative say let's get away altogether from this system that's built on profit, and let's move in the direction of cooperation, because that way we'll be able to survive future crises, and you can see simply that a group capable of organising itself and that's going to be in contact with farmers is simply in a position to survive in the city, you could say that, so it seems an important element to me, but it's also building bonds in general (I 12).

The above quote illustrates the attitudes presented by our interviewees delegitimating the economic system. Some respondents said outright that capitalism as such, and including the Polish version of post-transformational capitalism, is an unjust and socially damaging system. They therefore understood the actions they were taking either as reactions to the disfunctions of the economic system or as attempts towards creating a way of managing based on different principles than is the case in capitalism. Some writers speak openly of transformational trauma as the cause of the emergence and spread of informal movements in Poland, including in particular those aiming to promote a social economy (Herbst 2013). In their opinion, the answer to the blocking of opportunities for realising important goals in life caused by the transformation and, in its wake, the liberal economic politics, was for many social groups the adoption of innovative strategies or withdrawal, and in extreme cases - rebellion (Herbst 2013: 9-10). If we accept that the economic crisis in western countries reinforced the negative consequences of the economic breakthrough in Poland, then one should expect that the social reactions described above will manifest themselves, if not at the start of the transformation, then precisely in a period of crisis.

\section{AGAINST DIVISIONS INTO US AND THEM IN POLITICS - A PERSPECTIVE OF POST-IDENTITY AND COOPERATION}

One of the more prominent areas of criticism of the political system in the broader sense in our research was its manner of functioning, based on narrowly understood interests and self-centredness. Our interviewees deprecated approaches of such a nature, both by pointing to the values and principles of particular importance to them, and when talking about the practices applied in their organisations.

The respondents indicated explicitly that the organisations they represent aim to develop such principles as social solidarity, cooperation, integration, networks of connections and social capital. One could describe this group of values in general as related to cooperation. In the respondents' comments, they were frequently tied to democratisation, participation, and giving a say to those excluded. On the whole, our interlocutors presented cooperation as a value whose nature could be described as societal, pragmatic, and sometimes even technical. One of the respondents expressed this in the following manner: 
we are striving to build up social trust, to build not cliques but rather a network of cooperation, to show (...) cooperation, sharing, the inclusion of diverse people, (...) and well we're making use of that synergy effect (I 3).

In addition, the notion of cooperation as understood by the respondents was based on the assumption that social diversity should be respected; the more diverse and the greater the network of a particular organisation, the more beneficial. We were told:

values (...) friendship I think, tolerance I guess... sort of tolerance understood as diversity, in the sense of a kind of respect for diversity and values, it's... I don't know, maybe you can find the word, because it's about it being a friendly neighbourhood, meaning, damn, that people feel good living in this city (I 8).

However, it would be a simplification to classify our respondents as left-wing. They frequently distanced themselves from being perceived in such a way, distinctly declaring themselves apolitical. Only some of the groups we surveyed described themselves as anarchistic. In general, however, our interviewees did not want to be perceived as representing a specific political option, and they emphasised that their goals were above political divisions. Their activities were therefore pragmatic - based on the assumption that the organisation's essence is the achievement of the goal, and not tribal group solidarity, or quarrels over imponderabilia. Cooperation as a value distinctly meant for them something that could be called a post-identity perspective: the rejection of narrow identities as outdated and excluding platforms capable of making the achievement of social goals impossible. Goal orientation can be seen, for example, in the comments quoted below:

We strive very hard not to be attached for example to a single political party, and we also try to talk to everybody, particularly as the situation of the current government is such that we might not have anybody to talk to at all if we were to start setting various criteria, so we don't set them, we talk to those who want to listen to us, and who want to hear our arguments (I 15).

Another organisation:

I don't think there are such organisations that wouldn't be able to function here, because as the name itself indicates (...), that one of the fundamental assumptions is openness to collaboration, and it might even be that we don't ordinarily agree with somebody, with what a particular organisation does, but if they have something to propose that fits into the context here, then sure, come along! (I 14).

A few groups and organisations therefore emphasised that the very creation of broad social and inter-organisational networks was their main value and area of activity. Among the other organisations, the networking of other groups and circles was frequently a method of obtaining support among followers and allies, or furthered the organising of resources, competences, and funds essential for carrying out their missions and goals. Openness towards broad-scale cooperation was acknowledged as both a pragmatic solution and a civil virtue standing in contradiction to the self-in- 
terestedness of politicians. The representatives of the groups we talked to therefore provided numerous examples of activities favouring the formation of broad networks. They frequently embraced strategies that would not stand a chance in traditional organisational activities. These included joining many broad coalitions implementing varied goals, surrendering their own group's interests, or not revealing the identity or even the name of the group so as to accomplish goals together, and not applying self-promotional strategies.

The method of conduct our interlocutors spoke of was meant to break with the models dominating in political practice. The object of delegitimation here is therefore the practising of self-interested politics and economics. 'Politicking', a focus on affiliation (including to parties) characteristic of the political system, on the self-centred interests of a narrow group and the force-based resolving of disputes was contrasted in our interviewees' comments with pragmatic cooperation in which abandoning narrowly-understood interests contributes to a more effective resolving of group problems.

\section{THE SEARCH FOR A BETTER FORMULA FOR DEMOCRACY}

The third topic evident in our interviews concerned the delegitimation of the prevailing models of the functioning of non-governmental organisations. However, the changes demanded are the result - we believe - of the respondents' adoption of a broader vision of the processes in democratic management and the manner in which power is exercised, and are a reaction to how Polish democracy has been experienced. The measures of many of the organisations we investigated, and which were presented to us, resulted from the reflection that traditional formulae for managing third sector bodies are faulty: they do not give one a sense of agency, they are rigid, and they are based on hierarchical dependences. This was also why our respondents emphasised that the groups they represent are rather a 'collective', a 'coalition', a 'partnership', 'brand' or 'social movement'. In a few of these organisations, our respondents even spoke of themselves as an 'anarchistic structure', which from the very beginning had not wanted to be formalised. They emphasised their otherness in relation to traditional organisations, even if representing one of them:

the story of (name of organisation) (...) began with a few people, who'd been working in other non-governmental organisations, deciding that they wanted to create a different kind of organisation that wouldn't make the same mistakes or model itself on those already existing (I 15).

In order to democratise the internal processes, the surveyed organisations developed, among other things, specific methods of management and decision taking. For some bodies, that meant functioning in the formula of a collective, in which the members take decisions jointly, including through deliberation over an online community forum. The leader was rotated in other organisations. In another, a local association that functioned as a social movement, it was indicated that the formal structure sometimes led to unnecessary friction and a prestige-related power play. Representatives of 
an organisation with much experience in drawing up participative models emphasised in turn that a flat decision-taking structure had led to the organisation displaying a reflective approach and allowed it to adjust better to the changing conditions. Remarks indicating obstacles related to the rigid structure imposed by formalisation and NGO status were also voiced among organisations long functioning in this area. Respondents indicated the time-consuming necessity of fundraising and the related bureaucracy, the inflexibility of activities restricted by the requirements of working according to the project method, and also - which is important - the necessity of steering goals in a way approved of by the sponsors, which was sometimes described (as one says in non-governmental jargon) as being at the sponsor's beck and call.

In some of the groups investigated, and especially the squats and the food cooperative, formalisation - and sometimes professionalisation - is contrasted with cordial interpersonal relations. Attention was drawn to the affiliative character of the 'informality', emphasising that such a formula allows almost family-like bonds to be maintained. Its key aspects are the absence of hierarchy or unequal resources of power. This, according to our interlocutors, gives a greater sense of security and identification than occurs in classic NGO structures - many of which have transformed (as the respondents pointed out) in the direction of corporations. You can't have a community and an hierarchy together - they are mutually exclusive states, we were told. The bonds of community are supposed to provide not only support for the individuals, but also empowerment for the group as a whole, firstly due to the fact that they are formed by strong individuals, and secondly because the group's goals were internalised in the process of their democratic coordination. This mechanism was presented to us as another way of achieving effectiveness, not forced by procedures or the system of rewards and punishments characteristic of classic organisations.

The second group of values that our respondents talked about in relation to ways of exercising power may be classed under the category of civil activity. Apart from such activeness mentioned directly, the respondents also indicated related principles, such as the empowering of groups and persons, having a say, inclusion in decision-making processes, and cultural promotion. These values were emphasised both by groups oriented towards functioning within the sphere of public policy and by organisations focused on achieving concrete political goals (for example in a local government body), but also by the majority of organisations that understood their goal as supporting those who had become excluded, as well as newly-emerging civil groups. In this sense the groups investigated clearly accept democratic values - rejecting the hierarchical and paternalistic ways of exercising power practised by the governing elites.

\section{MEASURES FAVOURING SUSTAINABLE DEVELOPMENT AND GLOCALISATION}

The fourth area of delegitimation of the system indicated in the interviews was related to the broadly understood influence of management on the environment. Our interlocutors distinctly emphasised the necessity for change in the relations between the economy and the natural environment. For most of the organisations investigated, the ecological aspect of their activities was very important. A picture emerges from 
the interviews of the organisations having a very broad understanding of ecological goals. This embraces influence on urban spatial planning procedures, improvement in local city planning policy, combatting air pollution, promoting small-scale trade and local farmers in order to compete with the powerful enterprises, as well as activities towards justice in the world. We describe these political values and goals as the focusing of organisations on sustainable development in the broad sense. This specific attribute is particularly significant in our sample - with most of the organisations we surveyed working on some kind of redefining of the prevailing model of the economy, so as to create or promote a system that would ensure respect for social networks, interpersonal relationships, and the natural environment. Some of our respondents, and particularly from cooperatives and groups close to anarchism, expressed this attribute of their activity quite frankly, saying for example the following:

Well, in regard to such let's say ideological values, meaning concerning what the particular group is to fight for, then I'd say that it's sustainable development in the cities, and good condi... better conditions of work for those working in commerce, and I think really that another such important value is simply a certain vision of commerce (...) it's about what happens on the part of the authorities, and a discussion of substance with them, and on the other hand an attempt towards constructing some kind of political front, a kind of general awareness (I 15).

As such, the goals related to sustainable development are closely tied to the ideal of the alternative economy - a combination of social justice and care for the environment. Apart from the directly expressed anti-capitalist and anti-systemic justification, the aspiration for sustainable development sometimes took on more 'moderate' forms presented by our respondents. This refers to care for public space in cities, collective self-defence against invasive developers, or social urban gardens, and so on.

The activities of social groups and organisations described by our respondents, aiming to implement values related to the environment, reveal a glocalisation orientation. The recipients of the measures we were told about were most often neighbours and residents of the neighbourhood or city in which the surveyed groups functioned. The above-mentioned ecological goals were connected to the organisations' strong attachment to neighbourhood and localness; measures undertaken took place above all among and for the local population. Even if residents did not participate in the activities, they were considered citizens who were obviously entitled to make use of the achievements of a particular organisation. In addition, the measures - including those for the environment - were undertaken by some organisations in specific spaces of influence, including such as squats, social gardens, food cooperatives or neighbourhood communities. Activity indicating care for the local community, for the nature in the region, for ecological farming, and so on, but also attention paid to honest trade or responsible consumption, was perceived by our respondents as a contribution to the change that should be happening on a global scale. 


\section{CONCLUSION}

In the final section we refer to the research question, regarding the degree to which the activities of the alternative organisations we investigated can be treated as an expression of political protest, manifested in delegitimation of the political system, the character of this delegitimation, which areas of societal life are subjected to particular criticism, and to what extent they are a response to the turning point related to the worldwide economic crisis.

After all, an assumption in the Livewhat project was that civil society in the countries affected by the economic crisis would react with the emergence of alternative forms of resilience, which would not only mitigate the consequences of the crisis, but also - over the passage of time and with the growth in the scale of their activity would be able to germinate a new quality, including in a political sense. The research does indeed seem to provide confirmation of the hypothesis that an economic crisis affects the character of the activity of alternative organisations, their goals, and the missions they adopt. This impact occurred to less of a degree through how the consequences of the worldwide economic crisis were felt in Poland, and to a greater extent through reflection related to observation of the changes taking place in countries particularly affected, and associating them with the process of economic transformation initiated in Poland in the 1990s. The organisations anticipated, as it were, the possible consequences of this process in the future, and clearly linked it to the adoption of a liberal direction in the country's economic growth. Such reflection stimulated both criticism of the method of exercising power, the institutions via which the systemic transformation was carried out, and the creation of an outline for an alternative social order, but - as needs pointing out - with distinct acceptance for the fundamental rules of democracy. As such in the case of our organisations covered by this research we are not dealing with total delegitimation, but only partial - applying to selected aspects of the political system.

The criticism aimed at the political system applied above all to how democracy was practised, and especially its abandoning of respect for civil empowerment. However, it is important that this value is tied to another value of great importance to the respondents: democracy itself. Although the respondents did not mention this value directly, and it was not included in the catalogue of most important values, the activities of many of the organisations investigated derive from the reflection that the principles of democracy have not been implemented well in Poland, and in particular the development of forms and the practice of social involvement in decision-taking processes was given up on. The proposals formulated for improving the model of democracy tend to involve the rejection of representative democracy as not fulfilling its task, in favour of participative democracy involving broad-scale civil participation leading to co-governance in various areas of society. However, one could also say that it is leading to a different ethos of the citizen: as active, with agency, and responsible within the spatial boundaries set for oneself. We are therefore dealing with what Matynia, in relation to new social movements, calls the shifting of civil empowerment, or a 'revolution of rights' (Matynia 2016). 
A different model of the practice of democracy has been called for. This would occur in realms of influence, meaning either within real limited spaces in which this influence is possible (such as squats, food cooperatives, and neighbourhood communities), or in online spaces. Hence the strong orientation in activity towards localness, which is treated as a realm that can be embraced by civil control, providing opportunities for realising civil empowerment. A different vision of democratic practices could be seen especially in the example of the forming of structures in the groups investigated, and in their method of managing the organisation, characterised by a departure from hierarchy and the classic one-person leadership in favour of group leadership, and more importantly - the consensual taking of decisions. An attribute of practically all of the investigated groups was their experimenting with democratic practices, their search for a different, fairer model of power, a kind which empowers the individual to a greater degree, letting them feel influential. At the same time emphasis is placed very distinctly on cooperation, on inter-group solidarity, on self-help.

The political culture of the power elites, involving party favouritism, and the self-centred interests of groups and parties, as well as the adoption in public discourse of the principle of exclusion and tribal solidarity, not leading to a search for solutions to problems but only reinforcing ideological positions, became areas of delegitimation in almost all the organisations investigated. In their reaction to the behaviour of the political elites as described above, the respondents - both when commenting about them and when describing their own activities - adopted a post-identity perspective - which indicates an aversion in these organisations towards defining or justifying political goals, as well as in their defining of the beneficiaries in the sense of specific political identities or social categories. To give an example, left-wing or right-wing narratives were rare, as was the defining of groups in terms of poverty or age, since our respondents spoke rather of the need to work above divisions, of not supporting self-centred interests, of activity beneficial for all, and so on. Putting it more broadly, this desirable vision of democracy could be called cooperative. In some organisations, our respondents referred directly in this context to cooperative ideas from the turn of the twentieth century, and the vision of democracy that shaped them held by its creators (Błesznowski 2014).

Another dimension of the criticism and delegitimation of the political system concerned the direction taken by economic changes and the adoption of a sharply liberal course for the economy by successive governments in the early years of the systemic transformation, plus the intensification of its consequences at the time of the worldwide economic crisis. Respondents frequently indicated its effects in Poland, such as the destructive character of commerce based on large-scale shops, the contamination and degradation of the environment, reprivatisation and housing policy causing exclusion, and the alienation of local bonds. They also delegitimated liberalism as a general rule for economic growth adopted by many countries around the world.

The aspiration for change, as well as the intended scope of its impact, differs within the set of groups and organisations that we investigated. A significant portion of the organisations could be classified under the type of critical legitimacy, which we recall could be described as follows: a critical attitude towards the system, coupled 
with simultaneous acceptance for its fundamental principles, as well as involvement in lobbying for change. This portion of the organisations is active in the public sphere. Another type is that of those organisations among which we can class cooperatives and squats, as well as organisations managing specific spaces, enclosed within spaces of autonomy, while the change called for should occur - as was presented to us slowly, through an 'osmosis' of their practised lifestyle, based on principles other than those of the prevailing culture. This portion of organisations is close in this respect to the model of 'setting oneself up' in an unfavourable and frequently hostile social and cultural environment. This hostility is perceived as an effect of the domination of market forces over the good of society as a whole, and is manifested in the alienation of individuals, the self-interestedness of social groups (and politicians in particular), and the lack of respect for the environment, and so on.

This group of organisations covered by the study delegitimates the political system to the greatest degree, and the cultural system which is a consequence of it, while simultaneously expressing disbelief in the possibility of changing it. This is a response of withdrawal from the system, which Piotr Sztompka wrote about as a possible reaction to transformational trauma (cf. Herbst 2013). A risk for such groups is becoming shut away and functioning according to the model described by Jerzy Szacki in his book Spotkania z utopia as the 'utopia of the monastery'. It signifies a kind of group escapism, resigning from social change on a broader scale, loss of belief in the possibility of social transformations in exchange for the creation of a monastery: 'a monastery does not change the world, it forms an island on it', writes Szacki (1980: 60-62).

In regard to the theoretical deliberations presented above, we accept that a portion of the forms of urban movements observed, including part of our research sample, even if expressing their aspirations in the language of 'the right to the city', is situated decidedly in the area of new politics characteristic of the forms of protest of new social movements representing the type of critical delegitimation discussed here, or in the type proposed for the requirements of this article, of legitimation through the proposing of innovation. The vast majority of these organisations are tied to the ideal of democracy, while at the same time criticising various forms in which the idea has been implemented in Poland by successive governing elites. The practice of governance is an object of particular criticism, its blade directed both towards institutions of the democratic order, whose purpose it is to implement these principles and values, and towards the power elites who are responsible for this practice (Pluciński 2019; Herbst 2013; Korolczuk 2015) as well as the model of liberal democracy based on capitalist ownership relations adopted at the beginnings of the transformation. We are therefore dealing with an anti-systemic and anti-capitalist stance towards the political reality of the period of transformation in Poland, strongly accentuated by the greater part of the research sample, but also by a significant portion of urban movements. We are of course aware of the restricted nature of the material we have available. Nevertheless, many of our observations made on a purposely selected group of 18 organisations are confirmed in other research studies conducted on civil groups similar to our organisations, and described in Polish literature as urban social movements (Herbst 2013; Kurnicki 2013; Bilewicz \& Potkańska 2013; Bilewicz 2015; Polańska 2015; Chimiak \& 
Iwińska 2015; Pluciński 2014; Pluciński \& Nowak 2017; Zielińska \& Wilczyńska 2019).

FUNDING: This research received no external funding.

CONFLICT OF INTEREST: The author declares no conflict of interest.

\section{REFERENCES}

Baglioni, Simone \& Marco Giugni eds. 2014. Civil society organizations, unemployment, and Precarity in Europe: Between service and policy. City: Palgrave Macmillan.

Beetham, David. 1991. The legitimation of Power. Basingstoke: Macmillan Education Ltd.

Bilewicz, Aleksandra. 2014. „Odnowa etosu społecznikowskiego? O inteligenckim charakterze niezinstytucjonalizowanych inicjatyw społecznych.” Pp. 47-76 in Krajobraz społecznościowy - Polska 2014, edited by G. Chimiak \& K. Iwińska. Warszawa: Collegium Civitas \& Centrum Wspierania Aktywności Lokalnej CAL.

Bilewicz, Aleksandra \& Dominika Potkańska. 2013. „Jak kiełkuje społeczeństwo obywatelskie? Kooperatywy spożywcze w Polsce jako przykład nieformalnego ruchu społecznego.” Trzeci Sektor 31(3): 25-44.

Błesznowski, Bartłomiej, ed. 2014. Kooperatyzm, spółdzielczość, demokracja. Wybór pism. Warszawa: Wydawnictwo Uniwersytetu Warszawskiego.

Castells, Manuel. 2013. Sieci oburzenia i nadziei. Ruchy społeczne $w$ dobie Internetu. [Networks of Outrage and Hope] Warszawa: PWN.

Castells, Manuel. 1982. Kwestia miejska. Trans. J. Piątkowski. Warszawa: PIW.

Chimiak, Galia \& Katarzyna Iwińska, eds. 2015. Krajobraz społecznościowy. Polska 2014. Warszawa: Collegium Civitas \& Centrum Wspierania Aktywności Lokalnej CAL.

Della Porta, Donatella \& Mario Diani. 2009. Ruchy społeczne. Wprowadzenie. Kraków: Wydawnictwo Uniwersytetu Jagiellońskiego.

Domanski, Henryk. 2004. „Czynniki legitymizacji w 21 krajach.” Nauka 4: 65-98.

Easton, David. 1965. A Systems Analysis of Political Life. New York: John and Wiley \& Sons.

Ekiert, Grzegorz \& Jan Kubik. 2015. "Civil Society in Postcommunist Europe - Poland in Comparative Perspective.” Pp. 39-62 in Civil Society Revisited: Lessons from Poland, edited by. K. Jacobsson \& E. Korolczuk. New York \& Oxford: Berghahn Books.

Garlicki, Jan. 2014. „Legitymizacja władzy i systemu politycznego. Aspekty teoretyczne.” Pp. 15-36 in Legitymizacja transformacji systemu politycznego $w$ Polsce, edited by J. Garlicki. Warszawa: Dom Wydawniczy ELIPSA.

Guest, Greg, Kathleen M. MacQueen, \& Emily E. Namey. 2011. Applied thematic analysis. Thousand Oaks, CA: Sage. 
Harvery, David. 2012. Bunt miast i miejska rewolucja. Warszawa: Wydawnicwo Bęc Zmiana.

Herbst, Krzysztof. 2013. Ruchy nieformalne a kierunki rozwoju ekonomii społecznej: Rekomendacje dla polityk publicznych. Warszawa: Centrum Rozwoju Zasobów Ludzkich.

Jacobsson, Kerstin, ed. 2015. Urban Grassroots Movements in Central and Eastern Europe. Farnham: Ashgate.

Jezierska, Katarzyna \& Dominika V. Polańska. 2018. “Social Movements Seen as Radical Political Actors: The Case of the Polish Tenants' Movement.” Voluntas 29: 683-696. https://doi.org/10.1007/s11266-017-9917-2

Klon Jawor. 2015. Podstawowe fakty o organizacjach pozarządowych 2015. Warszawa: Stowarzyszenie Klon/Jawor.

Kołtan, Jacek. 2016. „Czas przesilenia. O świecie, który nadchodzi.” Pp. 15-38 in Przesilenie. Nowa kultura polityczna, edited by J. Kołtan. Gdańsk: Europejskie Centrum Solidarności.

Kołtan, Jacek. 2014. „Jaka Solidarność przyszłości.” Pp. 139-149 in Solidarność i kryzys zaufania, edited by J. Kołtan. Gdańsk: Europejskie Centrum Solidarności.

Kowalewski, Maciej. 2016. Protest miejski. Przestrzenie, tożsamości i praktyki niezadowolonych obywateli miast. Kraków: Nomos.

Kowalewski, Maciej. 2020. „Protest miejski ale czy lokalny.” Pp. 37-47 in Aktywizmy miejskie, edited by B. Lewenstein, A. Gójska, \& E. Zielińska. Warszawa: Wydawnictwo Scholar.

Kubicki, Paweł. 2019. „Ruchy miejskie w Polsce. Dekada doświadczeń.” Studia Socjologiczne 3(234): 5-30. DOI: 10.24425/sts.2019.126150

Kurnicki, Karol. 2013. „(Nowe) ruchy miejskie w Polsce - w stronę socjologicznego opisu." Trzeci Sektor 3: 12-24.

Kriesi, Hanspeter. 1996. "The organizational structure of new social movements in a political context." Comparative perspectives on social movements 152-184. https:// doi.org/10.1017/CBO9780511803987.009

Lewenstein, Barbara \& Maria Theiss. 2018. „Obywatele w polityce nieinstytucjonalnej. Analiza działań alternatywnych grup i organizacji społecznych w sytuacji kryzysu ekonomicznego.” Pp. 151-190 in Obywatel na zielonej wyspie. Polityka społeczna i obywatelstwo społeczne $w$ Polsce $w$ dobie europejskiego kryzysu gospodarczego, edited by M. Theiss, A. M. Theiss, A. Kurowska, J. Petelczyc, B. Lewenstein. Warszawa: Wydawnictwo IFIS PAN.

Matynia, Elżbieta. 2016. „Zieleni się demokracja? Refleksje na marginesie Wiosny Arabskiej i nowych ruchów społecznych.” Pp. 79-102 in Nowa kultura polityczna, edited by J. Kołtan. Gdańsk: Europejskie Centrum Solidarności.

Melucci, Alberto. 1995. “The Process of Collective Identity.” Pp. 68-86 in Social Movements and Culture, edited by B. Johnston \& B. Klandermans. Mineapolis \& London: University of Minesota Press.

Mider, Daniel. 2014. "Uczestnictwo w polityce jako korelat legitymizacji systemu politycznego w procesie transformacji ustrojowej - ilościowa analiza związków.” Pp.73-101 in Legitymizacja transformacji i systemu politycznego w Polsce, edited by 


\section{J. Garlicki. Warszawa: Elipsa.}

Mider, Daniel. 2014b. "Wymiar społeczny konsolidacji demokracji w Polsce. Typologia postaw wobec systemu politycznego." Pp. 37-53 in Legitymizacja transformacji i systemu politycznego w Polsce, edited by J. Garlicki. Warszawa: Elipsa.

Offe, Claus. 1985. "New Social Movements: Challenging The Boundaries of Institutional Politics." Social Research 52(4): 817-868. http://www.jstor.org/stable/40970399

Offe, Claus. 1995. „Nowe ruchy spoleczne. Przekraczanie granic polityki instytucjonalnej.” Pp. 212-225 in Władza i społeczeństwo. Antologia tekstow z zakresy socjologii polityki, edited by J. Szczupaczyński. Warszawa: Wydawnictwo Naukowe Scholar.

Plucińśki, Przemysław. 2014. „'Miasto to nie firma' - dylematy i tożsamość polityczna miejskich ruchów społecznych we współczesnej Polsce.” Przegląd Socjologiczny 63(1): 137-170.

Pluciński, Przemysław \& Marek Nowak. 2017. „E Pluribus unum? Źródła i specyfika ruchów miejskich we współczesnej Polsce." Przegląd Socjologiczny 66(3): 115-135.

Polańska, Dominika V. 2014. „Motywacje osób niezinstytucjonalizowanego sektora społecznościowego.” Pp. 27-46 in Krajobraz społecznościowy - Polska 2014, edited by G. Chimiak \& K. Iwińska. Warszawa: Collegium Civitas \& Centrum Wspierania Aktywności Lokalnej CAL.

Piotrowski, Grzegorz \& Dominika V. Polańska. 2016. "Radical Urban Movements in Poland - the case of squatting.” Miscellanea Anthropologica et Sociologica 17(1): 53-69.

Pobłocki, Kacper, Lech Mergler \& Maciej Wudarski. 2013. Anty-Bezradnik przestrzenny: prawo do miasta $w$ działaniu. Warszawa: Biblioteka Res Publiki Nowej.

Lefebvre, Henri. 2012. „Prawo do miasta.” Praktyka Teoretyczna 5: 183-197. https://doi. org/10.14746/prt.2012.5.14

Szacki, Jerzy. 1980. Spotkania z utopia. Warszawa: ISKRY.

Touraine, Alain. 1995. „Wprowadzenie do analizy ruchów społecznych.” Pp. 212-220 in Władza i społeczeństwo. Antologia tekstow z zakresy socjologii polityki, edited by J. Szczupaczyński. Warszawa: Wydawnictwo Naukowe Scholar.

Zielińska, Ewa \& Anna Wilczyńska. 2019. „Miejskie autonomie jako laboratoria zarządzania przestrzenią $\mathrm{w}$ partnerstwie publiczno-społecznym - studium przypadku Otwartego Jazdowa w Warszawie.” Trzeci Sektor 45: 18-27. DOI: $\underline{10.26368 / 17332265-045-1-2019-1}$

\section{BIOGRAPHICAL NOTE}

Barbara Lewenstein: associate professor. Works at the Institute of Applied Social Sciences of the University of Warsaw, as Deputy Director of Academic Affairs since 2016. She has been studying matters of civil engagement and localness for many years, and has penned over 50 papers in this area. Currently the head of the Sociourbanistyka specialisation path, while also actively involved in practice in projects connected to participatory spatial development and town planning. 
OPEN ACCESS: This article is distributed under the terms of the Creative Commons Attribution Non-commercial License (CC BY-NC 4.0) which permits any non-commercial use, and reproduction in any medium, provided the original author(s) and source are credited.

ARTICLE HISTORY: Received 2020-02-10 / Accepted 2020-09-25 